\title{
ANALISIS FAKTOR-FAKTOR YANG MEMPENGARUHI KEPUTUSAN KONSUMEN MEMILIH PRODUK ROTI DI UKM ROTI AISYAH PEJOGOL
}

\author{
Yuliyanti Dian Pratiwi ${ }^{1)}$, Nurul Hidayati ${ }^{2)}$, Retno Purnomo ${ }^{3)}$ \\ ${ }^{1,2,3)}$ STT Wiworotomo, Jalan Semingkir No 1, Purwokerto \\ ${ }^{1)}$ dianhilal@gmail.com,${ }^{2}$ noeroel1982@gmail.com,${ }^{3)}$ retnopurnomo321@gmail.com
}

\begin{abstract}
Received:

$06 / 01 / 2021$

The food processing industry sector is increasingly experiencing a level of intense competition. This is because the increase in consumer purchasing power has an impact on high consumer demand and that consumer behavior in purchasing

Accepted : decisions is increasingly selective. UKM Roti Aisyah, there were problems and

09/01/2021 consumer complaints, entrepreneurs must think of the right strategy to attract consumer interest. One way with find out what are the factors that influence

Published:

21/01/2021 consumers in choosing products, especially bread. The purpose of this study is to determine the factors of consumer decisions to be considered in choosing a case study of bread products at UKM Roti Aisyah, to examine among consumer decision factors what factors are most considered by consumers choosing bread product at UKM Roti Aisyah. The research method is descriptive qualitative approach that aims to describe the objective conditions of the analysis of the factors that influence consumer decisions in choosing bakery products. The results show that The dimensions of consumer decisions are taken into consideration in choosing bread products. The case study at UKM Roti Aisyah is that from the 12 factors analyzed, 3 new factors can be formed and the dimensions of consumer decisions that are most considered by consumers in choosing bread products in the case study of UKM Roti Aisyah are the first factor, the forming indicator is price affordable, products that have many variants, wrappers and payments.
\end{abstract}

Keywords: Consumer Decisions, Factor Analisis, Correlation Matriks, Component Transformation Matriks

\begin{abstract}
Abstrak
Sektor industri pengolahan makanan semakin mengalami tingkat persaingan yang ketat. Hal ini karena peningkatan daya beli konsumen yang berdampak pada tingginya permintaan konsumen dan perilaku konsumen dalam keputusan pembelian semakin selektif. UKM Roti Aisyah mempunyai masalah dan keluhan konsumen, pengusaha harus memikirkan strategi yang tepat untuk menarik minat konsumen. Salah satu cara dengan mengetahui apa yang yang menjadi faktor yang mempengaruhi konsumen dalam memilih produk, khususnya roti. Tujuan dari penelitian ini adalah untuk mengetahui faktor-faktor keputusan konsumen menjadi pertimbangan dalam memilih produk roti studi kasus pada UKM Roti Aisyah, untuk menguji diantara faktor keputusan konsumen faktor apakah yang paling dipertimbangkan konsumen dalam memilih produk roti studi kasus pada UKM Roti Aisyah. Metode penelitiannya adalah pendekatan kualitatif deskriptif yang bertujuan untuk menggambarkan kondisi obyektif tentang analisis faktor-faktor yang mempengaruhi keputusan konsumen dalam memilih produk roti. Hasil penelitian menunjukkan bahwa Faktor-faktor keputusan konsumen menjadi pertimbangan dalam memilih produk roti studi kasus pada UKM Roti Aisyah adalah dari 12 faktor yang dianalisis dapat terbentuk 3 faktor baru dan faktor keputusan konsumen yang dominan paling dipertimbangkan konsumen dalam memilih produk roti studi kasus pada UKM Roti Aisyah adalah faktor pertama dengan indikator pembentuknya yaitu keterjangkauan harga, produk yang memiliki banyak varian, pembungkus dan pembayaran.
\end{abstract}

Kata Kunci: Keputusan Konsumen, Analisa Faktor, Matriks Korelasi, Komponen Transformasi Matriks. 


\section{Pendahuluan}

Upaya memahami perilaku konsumen perlu dilakukan untuk memahami terhadap perilaku konsumen yang menjadi kunci keberhasilan dalam kegiatan usahanya. Melalui pemahaman perilaku konsumen, pihak manajemen dapat menyusun strategi dan program yang tepat dalam rangka memanfaatkan peluang yang ada dalam rangka memenangkan persaingan dalam sektor industri pengolahan makanan yang semakin ketat. Dari hasil survey awal yang dilakukan ke Roti Aisyah, didapat masalah dan keluhan konsumen untuk Roti Aisyah. Berdasarkan informasi dari pemilik usaha Roti Aisyah, masalah yang dihadapi adalah banyak bermunculan pesaing dalam usaha roti yang baru. Untuk dapat memenangkan persaingan UKM roti, harus memikirkan strategi yang tepat untuk menarik minat konsumen. Salah satu cara untuk menarik minat konsumen adalah dengan mengetahui apa yang yang menjadi faktor yang mempengaruhi konsumen dalam memilih produk, khususnya roti.

"Sutrisyo dan Tecoalu (2016), keputusan membeli produk juga dapat dipengaruhi oleh faktor-faktor yaitu, merek, harga, kualitas, kemasan, dan layanan”. Sedangkan "Irawan dan Wijaya (2010), menggambarkan pilihan dan membentuk maksud untuk membeli. Keputusan membeli produk juga dapat dipengaruhi oleh faktor-faktor yaitu, merek, harga, kualitas, kemasan dan layanan. Menggambarkan pilihan dan membentuk maksud untuk membeli pada perilaku konsumen ini akan menjadi acuan konsumen dalam mengambil keputusan pembelian".

Proses membeli konsumen diawali saat pembeli menyadari adanya masalah kebutuhan. Memahami konsumen dan mengembangkan strategi pemasaran yang tepat harus memahami apa yang dipikirkan, dirasakan serta dilakukan oleh konsumen. Tujuan pemenuhan kebutuhan maupun keinginan adalah tercapainya tingkat kepuasan konsumen. "Sudrajat dan Andriani (2015), menjelaskan atribut produk adalah unsurunsur produk yang dipandang penting oleh konsumen yang dapat dijadikan dasar untuk mengambil keputusan pembelian. Atribut produk adalah faktor yang dipertimbangkan oleh konsumen dalam mengambil keputusan pembelian suatu produk seperti harga, merek, kualitas, kemasan, kelengkapan fungsi dan layanan purna jual”.

Menurut "Sutrisyo dan Tecoalu (2016), yang meneliti Faktor-faktor yang mempengaruhi Keputusan Pembelian Kue Sorabi Hijau Rengasdengklok yang menunjukkan bahwa variabel harga dan word of mouth tidak berpengaruh positif terhadap keputusan pembelian Kue Sorabi Rengasdengklok. Sedangkan variabel-variabel citra merek, kualitas produk, dan lokasi berpengaruh positif terhadap keputusan pembelian Kue 
Sorabi Rengasdengklok”. Menurut "Syafirah, Lisbeth Mananeke, Jopie Jorie Rotinsulu (2017), yang meneliti Pengaruh Faktor-Faktor Perilaku Konsumen Terhadap Keputusan Pembelian Produk pada Holland Bakery Manado yang menunjukkan bahwa yang dilakukan variabel budaya, sosial dan psikologis berpengaruh signifikan terhadap keputusan pembelian produk pada Holland Bakery Manado". Menurut "Mayangsari dan Irawati (2018), yang meneliti Analisis Faktor-Faktor Yang Dipertimbangkan Konsumen dalam Keputusan Pembelian Produk Kek Pisang Villa Kota Batam hasil penelitian menunjukkan dari 20 indikator yang dianalisis, dapat terbentuk 6 faktor baru yaitu faktor Kualitas Produk, Brand Image, Harga Produk, Bentuk Kemasan, Pesaing dan Mutu Kemasan. Sedangkan faktor yang paling dominan dipertimbangkan konsumen dalam keputusan pembelian produk Kek Pisang Villa adalah faktor Kualitas Produk dengan nilai varians sebesar $24.322 \%$ ".

Perbedaan penelitian ini dengan penelitian terdahulu adalah penelitian ini fokus pada variable harga, merek, kualitas, kemasan dan layanan dan analisa data menggunakan analisa faktor. Dan berdasarkan perumusan masalah tersebut, tujuan yang akan dicapai dalam penelitian ini adalah mengetahui faktor-faktor keputusan konsumen yang digunakan sebagai pertimbangan dalam memilih produk roti studi kasus UKM Roti Aisyah dan mengetahui faktor yang paling dipertimbangkan dalam memilih produk roti pada UKM Roti Aisyah.

\section{Metode Penelitian}

Penelitian ini dilakukan pada bulan Mei s/d Juni 2020 di outlet penjualan roti dari UKM Roti Aisyah Pejogol Kecamatan Cilongok Kabupaten Banyumas. Metode penelitian menggunakan pendekatan kuantitatif deskriptif, yang bertujuan untuk menggambarkan kondisi obyektif tentang analisis faktor-fator yang mempengaruhi keputusan konsumen dalam memilih produk roti (Sugiyono,2016).

Teknik pengumpulan data menggunakan Kuesioner. Variabel-variabel dalam penelitian ini diukur dengan menggunakan skala Likert yaitu untuk mengungkapkan perasaan responden dengan memilih lima alternatif jawaban dengan mengambil sampel 100 konsumen di outlet penjualan roti UKM Roti Aisyah.

Analisa data menggunakan analisa faktor dengan bantuan software SPSS, diawali melakukan uji validitas dan reabilitas untuk menguji validitas tiap item instrument dengan mengkorelasikan antara skor-skor tiap item dengan skor total keseluruhan instrument. 
Item dikatakan valid, jika $\mathrm{r}$ hitung $>\mathrm{r}$ tabel, selanjutnya mereduksi atau meringkas dari banyak variabel ke dalam satu atau beberapa faktor.

Tahapan dalam analisis faktor dapat dijelaskan sebagai berikut, pertama menyusun matriks korelasi, metode statistik yang digunakan untuk menguji model faktor berdasarkan korelasi antar variabel KMO (Kayser- Meiyer-Olkin) atau bartlett's test. Secara empiris besarnya KMO minimal 0,5. Bila KMO di atas atau sama dengan 0,5 maka penelitian tersebut dapat dilanjutkan ke tahap berikutnya. Kedua, melakukan ekstraksi faktor, dengan metode Principle Component. Dalam metode ini diagonal matriks korelasi diganti dengan Communality. Proses ini dilakukan berulang-ulang sampai besarnya angka tidak mengalami perubahan. Ketiga, menentukan jumlah faktor menggunakan kriteria bahwa faktor yang dimasukkan ke dalam model adalah faktor yang memiliki eigen value lebih besar dari 1,00, metode ini dikenal dengan determination Based On Eigen Value. Tahap akhir, melakukan rotasi dan penamaan faktor, metode rotasi dikatakan baik jika keluaran atau output loading factor benar-benar terpisah atau dapat juga dikatakan jika tidak ada variabel yang masuk ke dalam lebih dari satu faktor dan penamaan faktor diambil pada variabel yang mempunyai nilai loading $>0,5$.

\section{Hasil dan Pembahasan}

Dalam penelitian ini terdiri dari lima variabel yaitu variabel merek, harga, kualitas, kemasan dan layanan, selanjutnya dilakukan analisa faktor dengan langkah awal dengan melakukan uji validitas dan uji reabilitas, menggunakan bantuan software SPSS dengan nilai dari pengujian sebesar 0,1654 dengan $\mathrm{df}=\mathrm{n}-1$ dan taraf signifikan 0.05 (5\%) diperoleh hasil berikut:

Tabel 1. Hasil Uji Validitas

\begin{tabular}{|c|c|c|c|}
\hline Variabel & Sub Variabel & $\begin{array}{c}\text { Koefisien } \\
\text { Korelasi }\end{array}$ & Ket. \\
\hline \multirow{2}{*}{$\begin{array}{c}\text { Merek } \\
(\mathrm{X} 1)\end{array}$} & (X1.1) Produk berdasar kepercayan merek & 0,629 & Valid \\
\hline & (X1.2) Produk berdasarkan reputasi merek & 0,657 & Valid \\
\hline \multirow{3}{*}{$\begin{array}{l}\text { Harga } \\
(\mathrm{X} 2)\end{array}$} & (X2.1) Keterjangkauan harga & 0,723 & Valid \\
\hline & (X2.2) Kesesuainan produk dengan kualitas & 0,591 & Valid \\
\hline & (X2.3) Kesesuaian harga dengan manfaat & 0,599 & Valid \\
\hline \multirow{2}{*}{$\begin{array}{c}\text { Kualitas } \\
\text { (X3) }\end{array}$} & (X3.1) Produk yang memiliki banyak varian & 0,671 & Valid \\
\hline & (X3.2) Produk pilihan utama konsumen & 0,558 & Valid \\
\hline \multirow{2}{*}{$\begin{array}{c}\text { Kemasan } \\
(\mathrm{X} 4)\end{array}$} & (X4.1) Perancangan & 0,402 & Valid \\
\hline & (X4.2) Pembuatan wadah (pembungkus) & 0,744 & Valid \\
\hline \multirow{3}{*}{$\begin{array}{l}\text { Layanan } \\
\text { (X5) }\end{array}$} & (X5.1) Informasi & 0,628 & Valid \\
\hline & (X5.2) Ordering & 0,572 & Valid \\
\hline & (X5.3) Pembayaran & 0,748 & Valid \\
\hline
\end{tabular}


Semua instrumen variabel keputusan konsumen adalah valid, karena terbukti bahwa nilai koefisien lebih besar dari nilai kritik atau tabel pada tingkat signifikan $5 \%$. Dan Uji Reabilitas untuk melihat reabel atau tidak, dilakukan dengan melihat koefisien reliabilitas (coefisient of reliability). Nilai koefisien tersebut berkisar antara 0 hingga 1. Semakin mendekati 1 menunjukkan makin reliabel. Ukuran yang dipakai untuk semakin reliabel bilamana Cronbach's Alpha diatas 0,6. Adapun hasil uji reliabilitas dapat dilihat pada tabel 2 berikut:

Tabel 2. Hasil Uji Reabilitas

\begin{tabular}{|c|c|c|}
\hline No & Variabel & Nilai MSA \\
\hline 1 & (X1.1) Produk berdasarkan kepercayaan merek & 0,761 \\
\hline 2 & (X1.2) Produk berdasarkan reputasi merek & 0,860 \\
\hline 3 & (X2.1) Keterjangkauan harga & 0,615 \\
\hline 4 & (X2.2) Kesesuainan produk dengan kualitas produk & 0,634 \\
\hline 5 & (X2.3) Kesesuaian harga dengan manfaat & 0,813 \\
\hline 6 & (X3.1) Produk yang memiliki banyak & 0,825 \\
\hline 7 & (X3.2) Produk pilihan utama konsumen & 0,566 \\
\hline 8 & $(\mathrm{X} 4.1)$ perancangan & 0,783 \\
\hline 9 & (X4.2) pembuatan wadah (pembungkus) & 0,593 \\
\hline 10 & (X5.1) Informasi & 0,677 \\
\hline 11 & (X5.2) Ordering & 0,572 \\
\hline 12 & (X5.3) Pembayaran & 0,683 \\
\hline
\end{tabular}

Faktor yang dibentuk adalah variabel-variabel yang berkorelasi signifikan. Pada analisa faktor tahap ini dilakukan uji Measure of Sampling Adequacy (MSA). Pada langkah ini, dilakukan uji Barlet Test of Spericity, berdasarkan hasil analisis dapat diperoleh dengan KMO and Barlett's Test. Untuk uji kesesuaian analisis faktor dapat dilihat pada tabel 3 berikut ini.

Tabel 3. Hasil Uji Kesesuain Analisis Faktor KMO and Bartlett's Test

\begin{tabular}{|c|c|c|}
\hline \multicolumn{2}{|c|}{ Kaiser-Meyer-Olkin Measure of Sampling Adequacy. } & \multirow{2}{*}{$\begin{array}{r}0,671 \\
669,084\end{array}$} \\
\hline Bartlett's Test of Sphericity & Approx. Chi- & \\
\hline & $D f$ & 66 \\
\hline
\end{tabular}


Dari hasil ekstraksi faktor diperoleh 3 faktor yang mempunyai eigen value di atas 1 dengan persentase cumulative variance sebesar 66,420. Untuk mengetahui hasil ekstraksi faktor dapat dilihat pada tabel 5 berikut.

Tabel 5. Hasil Ekstraksi Faktor

\begin{tabular}{cccc}
\hline \multirow{2}{*}{ Component } & \multicolumn{3}{c}{ Initial Eigenvalues } \\
\cline { 2 - 4 } & Total & \% of Variance & Cumulative \% \\
\hline 1 & 4,85 & 40,435 & 40,435 \\
\hline 2 & 2,01 & 16,754 & 57,190 \\
\hline 3 & 1,10 & 9,230 & 66,420 \\
\hline 4 & 0,98 & 8,190 & 74,609 \\
\hline 5 & 0,73 & 6,138 & 80,747 \\
\hline 6 & 0,64 & 5,401 & 86,148 \\
\hline 7 & 0,46 & 3,881 & 90,030 \\
\hline 8 & 0,38 & 3,200 & 93,230 \\
\hline 9 & 0,31 & 2,600 & 95,830 \\
\hline 10 & 0,30 & 2,500 & 98,329 \\
\hline 11 & 0,12 & 0,997 & 99,326 \\
\hline 12 & 0,08 & 0,674 & 100,000 \\
\hline
\end{tabular}

Berikut ini adalah penjelasan dan langkah-langkah mengenai hasil pengolahan data dengan menggunakan analisis faktor.

Tabel 6. Component Matrix

\begin{tabular}{lccc}
\hline \multicolumn{1}{c}{ Variabel } & \multicolumn{3}{c}{ Component/ Faktor } \\
\cline { 2 - 4 } (X1.1) Produk berdasarkan kepercayaan merek & $\mathbf{1}$ & $\mathbf{2}$ & $\mathbf{3}$ \\
\hline (X1.2) Produk berdasarkan reputasi merek & 0,691 & 0,344 & 0,478 \\
\hline (X2.1) Keterjangkauan harga & 0,758 & 0,017 & $0,0,558$ \\
\hline (X2.2) Kesesuainan produk dengan kualitas produk & 0,576 & 0,322 & 0,085 \\
\hline (X2.3) Kesesuaian harga dengan manfaat & 0,566 & 0,180 & 0,306 \\
\hline (X3.1) Produk yang memiliki banyak varian & 0,693 & 0,294 & 0,126 \\
\hline (X3.2) Produk pilihan utama konsumen & 0,520 & 0,360 & 0,439 \\
\hline (X4.1) Perancangan & 0,351 & 0,698 & 0,092 \\
\hline (X4.2) Pembuatan wadah (pembungkus) & 0,706 & 0,356 & 0,374 \\
\hline (X5.1) Informasi & 0,669 & 0,643 & 0,187 \\
\hline (X5.2) Ordering & 0,582 & 0,604 & 0,034 \\
\hline (X5.3) Pembayaran & 0,771 & 0,372 & 0,253 \\
\hline
\end{tabular}


Koefisien faktor loading menunjukkan korelasi antara faktor dan variabel, dimana suatu koefisien dengan nilai besar menunjukkan bahwa faktor dan variable berkaitan erat. Berdasarkan hasil analisis faktor maka dihasilkan 3 faktor yang dipertimbangkan dalam keputusan konsumen dalam memilih produk roti Aisyah. Adapun secara lengkap hasil analisis faktor dapat dilihat pada tabel 7.

Tabel 7. Hasil Analisis Faktor

\begin{tabular}{llccc}
\hline \multicolumn{1}{c}{ Nama Faktor } & \multicolumn{1}{c}{ Variabel } & $\begin{array}{r}\text { Nilai } \\
\text { Loading }\end{array}$ & $\begin{array}{c}\text { Eigen } \\
\text { Value }\end{array}$ & Varian \\
\hline Faktor 1 & (X2.1) Keterjangkauan harga & 0.758 & 4.852 & 40.435 \\
$\begin{array}{l}\text { (pembayaran dan } \\
\text { keterjangkauan } \\
\text { harga) }\end{array}$ & $\begin{array}{l}\text { (X3.1) Produk yang memiliki } \\
\text { banyak varian }\end{array}$ & 0.693 & & \\
\hline Faktor 2 & (X4.2) Pembuatan wadah & 0.706 & & \\
(Perancangan dan & (X4.1) Perancangan & 0.698 & 2.011 & 16.754 \\
\hline Faktor 3 (Reputasi & (X1.2) Produk berdasarkan & 0.643 & & \\
merek) & reputasi merek & 0.558 & & \\
\hline \multicolumn{1}{c}{ Komponen } & matrik dari proses rotasi & (Rotated & Componen & Matriks $)$
\end{tabular}

memperlihatkan distribusi variabel yang lebih jelas dan nyata. Dengan adanya proses rotasi faktor loading yang semakin diperkecil dan faktor loading yang semakin besar. Component Transformation Matrix dapat dilihat pada tabel 8.

Tabel 8. Component Transformation Matrix

\begin{tabular}{cccc}
\hline Component & $\mathbf{1}$ & $\mathbf{2}$ & $\mathbf{3}$ \\
\hline 1 & 0,631 & 0,553 & 0,544 \\
\hline 2 & $-0,775$ & 0,482 & 0,410 \\
\hline 3 & 0,036 & 0,680 & $-0,732$
\end{tabular}

Berdasarkan tabel 8, menjelaskan bahwa pada diagonal faktor (component) 1, 2, 3 (0.631, 0.482, -0.732). Angka dengan ditandai minus (-) hal tersebut menunjukkan arah korelasi. Sedangkan pada diagonal yang lain menunjukkan angka di bahwa 0,5 yang menunjukkan adanya terdapat komponen lain pada masing-masing faktor yang mempunyai korelasi tinggi. dan terdapat tiga yang angkanya di atas 0,5 yaitu: faktor 1 (component 1, 0.631), faktor 2 (component 2, 0.680), faktor 3 (component 3, 0.544). Berdasarkan terbentuknya tiga faktor hal ini sudah cukup mewakili atau merangkum dari ke dua belas variabel. 


\section{Kesimpulan}

Berdasarkan hasil penelitian dan pembahasan yang telah dilakukan, diperoleh kesimpulan, yaitu: dari 12 faktor yang dianalisis dapat terbentuk 3 faktor baru, yaitu faktor pertama (pembayaran dan keterjangkauan harga) dengan indikator pembentuknya yaitu keterjangkauan harga, produk yang memiliki banyak varian, pembuatan wadah (pembungkus) dan pembayaran, faktor kedua (perancangan dan informasi) dengan indikator pembentuknya yaitu perancangan, informasi dan ordering, faktor ketiga (reputasi merek) dengan indikator pembentuknya yaitu produk berdasarkan reputasi merek dan faktor keputusan konsumen yang paling dipertimbangkan konsumen dalam memilih produk roti studi kasus pada UKM Roti Aisyah adalah faktor pertama yaitu pembayaran dan keterjangkauan harga.

Saran untuk penelitian selajutnya adalah meneliti menggunakan variabel lain, misalnya kehigienisan kemasan dari faktor bahan kemasan yang dibuat, desain kemasan dan kemudahan dalam membuka kemasan produk. Dan menambah jumlah sampel penelitian serta menggunakan alat analisis data yang berbeda.

\section{Pustaka}

J.P. Frankel \& Wallen N.E. 2018. How to Design and Evaluate Research in Education, New York: McGraw-Hill Companies, Inc.

Kotler, Philip dan Gary Armstrong. 2015, Prinsip-prinsip Pemasaran. Jakarta: Erlangga.

Kotler, Philip. 2013, Manajemen Pemasaran, Jakarta: Erlangga.

Lupiyoadi, Rambat \& A. Hamdani. 2009, Manajemen Pemasaran Jasa. Jakarta: Salemba Empat.

Moenir. 2010, Manajemen Pelayanan Umum Di Indonesia, Jakarta: Bumi Aksara.

Prahalad, dan Varmestwary. 2009, Co Creation Competence Consumer, USA: Harvard Bussiness Review.

Prasetijo, Ristiyanti, dan Ihalauw, John. 2015, Perilaku Konsumen, Yogyakarta: Penerbit Andi.

Priyono, Fredy Agus. 2012, Analisa Faktor-Faktor Yang Dipertimbangkan Konsumen Dalam Membeli Minyak Goreng Merek Ikan Dorang (Study Kasus Pada PT Ikan Dorang Surabaya (tidak dipublikasikan), Surabaya: PPS Untag.

Rastini. 2011, Analisis Faktor-Faktor Yang Mempengaruhi Keputusan Menginap Di Hotel Berbintang Tiga, Surabaya: UNTAG.

Ratminto dan Atik. 2015, Manajemen Pelayanan. Yogyakarta. 
Sudrajad, A.B., Andriani, D.R. 2015, Pengaruh Atribut Produk Terhadap Keputusan Konsumen Dalam Pembelian Produk Abon Jamur Tiram di Perusahaan Ailanifood Kota Malang Jawa Timur, Jurnal Habitat, 26 (2).

Sugiyono. 2016, Metode Penelitian Kuantitatif, Kualitatif dan R\&D, Bandung: PT Alfabeta.

Sutrisyo, H. E., \& Tecoalu, M. 2016, Faktor-Faktor Yang Mempengaruhi Keputusan Pembelian Kue Sorabi Hijau Rengasdengklok, Manajemen Bisnis Kompetensi, 11(01).

Supangat, Aditya Hangga. 2017, Pengaruh Citra Merek, Kualitas Produk, Harga Terhadap Keputusan Pembelian, Jurnal Ilmu Dan Riset Manajemen, Vol 6 No 9.

Tjiptono, F. 2012, Strategi Pemasaran, Yogyakarta: Penerbit Andi. 
